Wright State University

CORE Scholar

2016

\title{
Temporal Variation of Mercury in Effluent from Two Municipal Wastewater Treatment Plants in Southwest Ohio
}

Heather Brittany Perusini

Wright State University

Follow this and additional works at: https://corescholar.libraries.wright.edu/etd_all

Part of the Earth Sciences Commons, and the Environmental Sciences Commons

\section{Repository Citation}

Perusini, Heather Brittany, "Temporal Variation of Mercury in Effluent from Two Municipal Wastewater Treatment Plants in Southwest Ohio" (2016). Browse all Theses and Dissertations. 1565.

https://corescholar.libraries.wright.edu/etd_all/1565

This Thesis is brought to you for free and open access by the Theses and Dissertations at CORE Scholar. It has been accepted for inclusion in Browse all Theses and Dissertations by an authorized administrator of CORE Scholar. For more information, please contact library-corescholar@wright.edu. 
TEMPORAL VARIATION OF MERCURY IN EFFLUENT FROM TWO MUNICIPAL WASTEWATER TREATMENT PLANTS IN SOUTHWEST OHIO

A thesis submitted in partial fulfillment of the

requirements for the degree of

Master of Science

By

HEATHER BRITTANY PERUSINI

B.A., Barnard College, 2013

2016

Wright State University 


\section{WRIGHT STATE UNIVERSITY \\ GRADUATE SCHOOL}

August 12, 2016

I HEREBY RECOMMEND THAT THE THESIS PREPARED UNDERMY SUPERVISION BY Heather Brittany Perusini ENTITLED Temporal Variation of Mercury in Effluent from Two Municipal Wastewater Treatment Plants in Southwest Ohio BE ACCEPTED IN PARTIAL FULFILLMENT OF THEREQUIREMENTS FOR THE DEGREE OF Master of Science.

Committee on

Final Examination

Chad Hammerschmidt, Ph.D.

Silvia Newell, Ph.D.

Marjorie Markopoulos, M.S.

Robert E. W. Fyffe, Ph.D.

Vice President for Research and

Dean of the Graduate School 


\begin{abstract}
Perusini, Heather Brittany, M.S. Department of Earth \& Environmental Sciences, Wright State University, 2016.Temporal Variation of Mercury in Effluent from Two Municipal Wastewater Treatment Plants in Southwest Ohio.
\end{abstract}

Mercury $(\mathrm{Hg})$ is a toxic metal that, once converted to methylmercury by microorganisms, bioaccumulates in aquatic food webs and poses a health risk to wildlife and humans who eat fish. Wastewater treatment plants (WWTPs) are a source of Hg to surface waters, but little is known about the temporal variability of $\mathrm{Hg}$ concentrations in effluent and efflux to aquatic systems. I quantified the concentration of $\mathrm{Hg}$ in effluent from the City of Dayton (Ohio) and Ford Road (Xenia, Ohio) WWTPs and examined temporal variability over monthly and hourly time scales as well as efficiency of $\mathrm{Hg}$ removal. Over a 13-month sampling period, $\mathrm{Hg}$ concentrations in effluent averaged 0.73 $\pm 0.20 \mathrm{ng} / \mathrm{L}$ and $4.18 \pm 1.45 \mathrm{ng} / \mathrm{L}$ for the Dayton and Xenia plants, respectively. Mercury concentrations in effluent from the Dayton plant did not differ among months, whereas effluent $\mathrm{Hg}$ concentrations from the Xenia WWTP decreased significantly over time, suggesting improved efficiency of $\mathrm{Hg}$ removal. Monthly averages of $\mathrm{Hg}$ concentrations in effluent varied by about a factor of two, similar to the hourly variability observed at the Xenia plant during a diurnal study. Both WWTPs removed Ó97\% of $\mathrm{Hg}$ from wastewater and are estimated to contribute $<5 \%$ of the total $\mathrm{Hg}$ loadings in their receiving waters. Although the concentrations of $\mathrm{Hg}$ in effluent from the Dayton WWTP 
were consistent over the year, there was significant variation in effluent $\mathrm{Hg}$ concentrations from the Xenia WWTP. This emphasizes the importance of systematic sampling and not generalizing results to broader time spans or to other sampling sites. 


\section{TABLE OF CONTENTS}

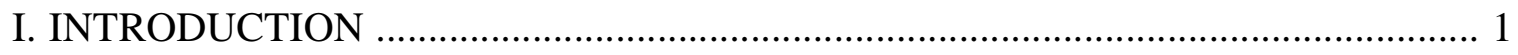

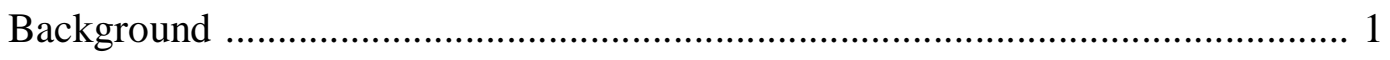

Research Hypotheses ...................................................................................... 3

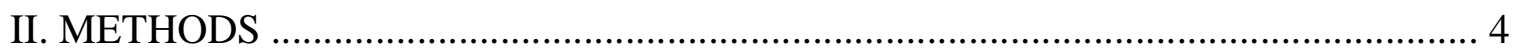

Wastewater Treatment Plants ........................................................................ 4

Effluent Sampling to Examine Temporal Variability ......................................... 5

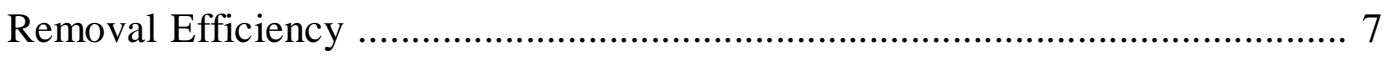

River Water Sampling ……………………………..................................... 7

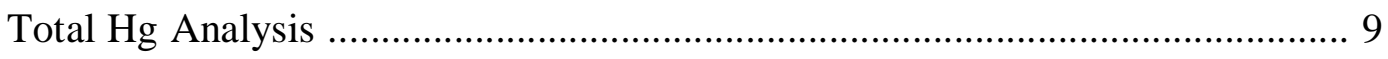

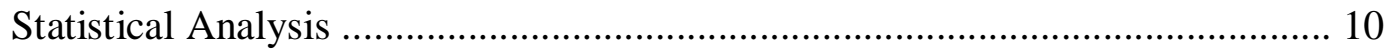

III. RESULTS AND DISCUSSION ………………............................................. 10

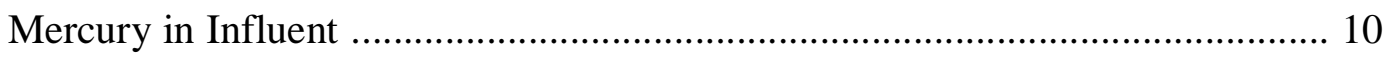

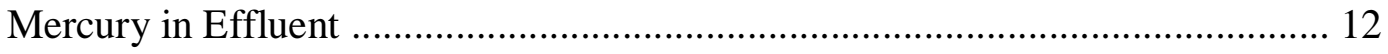

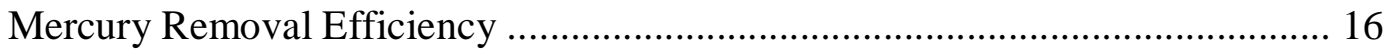

Diurnal Variation of Mercury in Effluent ………………................................ 19

Significance to Receiving Waters ....................................................................... 21

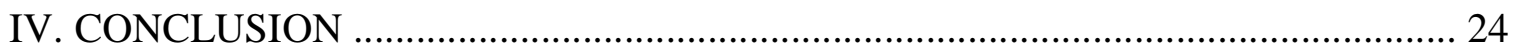

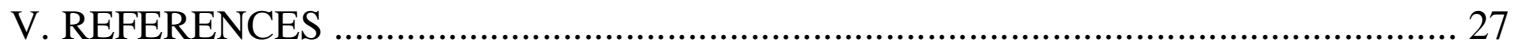




\section{LIST OF FIGURES}

Figure $\quad$ Page

1. Generalization of the wastewater treatment process at the City of Dayton and the Ford Road (Xenia, Ohio) wastewater treatment plants ........................................ 6

2. Sampling stages for multi-point study at Ford Road WWTP (Xenia, Ohio) ................ 8

3. Concentrations of total mercury $(\mathrm{Hg})$ in influent to the City of Dayton, Ohio, and Ford Road (Xenia, Ohio) WWTPs between April 2015 and April 2016 ................... 11

4. Mean $( \pm \mathrm{SD})$ total mercury $(\mathrm{Hg})$ concentrations in effluent from City of Dayton, Ohio and Ford Road (Xenia, Ohio) WWTPs from April 2015 to April 2016

5. Correlation between total $\mathrm{Hg}$ concentration and carbonaceous biochemical oxygen demand (CBOD) in effluent from the Ford Road WWTP in Xenia, Ohio $(p=0.03)$

6. Efficiency of $\mathrm{Hg}$ removal from City of Dayton, Ohio and Ford Road (Xenia, Ohio) WWTPs from April 2015 to April 2016

7. Total mercury $(\mathrm{Hg})$ concentrations in unfiltered wastewater at different points along the treatment process at the Ford Road Wastewater Treatment Plant in Xenia, Ohio

8. Total mercury $(\mathrm{Hg})$ concentrations in effluent sampled hourly from the Ford

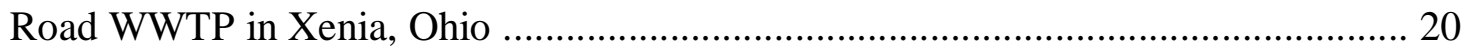

9. Monthly total mercury $(\mathrm{Hg})$ concentrations in effluent from the City of Dayton Wastewater Treatment Plant (mean \pm S.D.) and in the Lower Great Miami River (LGMR) upstream of the outflow pipe

10. Correlation between total $\mathrm{Hg}$ in the Great Miami River and instantaneous discharge upstream of the City of Dayton Wastewater Treatment Plant outflow $(p=0.003)$ 


\section{ACKNOWLEDGMENT}

I thank Alison Agather, Rachel Walker, Ryan Collins, Erica Strope, Ashlynn Boedecker, Katelynn Alcorn, and Kelly Muterspaw for help in either the field or

laboratory. I also thank Eddy Walker and the Ford Road Wastewater Treatment Plant and Karen Tenore and the City of Dayton Wastewater Treatment Plant. 


\section{INTRODUCTION}

Mercury is a toxic metal that, once converted to methylmercury by microorganisms (Benoit et al., 2003), bioaccumulates in aquatic food webs and poses a health risk to wildlife and humans who eat fish (Zahir et al., 2005; Mahaffey et al., 2009; Depew et al., 2012). Mercury enters aquatic systems principally from direct atmospheric deposition and watershed runoff (Swain et al., 1992; Fitzgerald et al., 2005). Other anthropogenic point sources include gold and mercury mines (Covelli et al., 2001; Thomas et al., 2002; Gehrke, Blum, and Marvin-DiPasquale, 2011), industrial inputs (Pirrone et al., 2010), and discharge from wastewater treatment plants (WWTPs; Balcom et al., 2004; Gbondo-Tugbawa et al., 2010). While loadings of $\mathrm{Hg}$ to surface waters from WWTPs are thought to be minor compared to other sources (i.e., $<10 \%$ of total; Bodaly et al., 1998; Balcom et al., 2004, 2008; Gbondo-Tugbawa et al., 2010; Fricke et al., 2015; Mao et al., 2016), relatively little is known about the temporal variability of $\mathrm{Hg}$ concentrations and fluxes in WWTP effluent as well as efficiency of $\mathrm{Hg}$ removal from the waste stream by the facilities.

During treatment, most $\mathrm{Hg}$ in wastewater is deposited in waste sludge (Balogh and Liang, 1995; Gilmour and Bloom, 1995; da Silva Oliveira et al., 2007; GbondoTugbawa et al., 2010; Fricke et al., 2015; Mao et al., 2016). Mercury has a high affinity for organic-rich particles (Hammerschmidt and Fitzgerald, 2004), which, if not efficiently removed from the waste stream, can result in elevated $\mathrm{Hg}$ concentrations in sediments near the discharge pipe relative to other nearby locations (Van Loon, 1974).

Although $\mathrm{Hg}$ is known to have potential detrimental effects to humans and aquatic ecosystems, a universal federal limit for the concentration of $\mathrm{Hg}$ in effluent from WWTPs 
has not been implemented. Instead, limits for $\mathrm{Hg}$ in effluent are set for individual WWTPs using EPA guidelines based on several factors, including, for example, $\mathrm{Hg}$ inputs to the facility, uses of waste sludge, and current levels of $\mathrm{Hg}$ in effluent (U.S. EPA, 2004).

Wastewater treatment processes remove most $\mathrm{Hg}$ from domestic wastewater. Previous studies have shown urban wastewater treatment plants in Winnipeg, Canada, remove, on average, $88 \%$ of $\mathrm{Hg}$ from raw sewage prior to effluent discharge (Bodaly et al., 1998). However, removal efficiencies can vary substantially among facilities in different countries, ranging, for example, from $62 \%$ in Sao Paulo, Brazil (da Silva Oliveira et al., 2007) to over 99\% in Frankfurt am Main, Germany (Fricke et al., 2015). The concentration of $\mathrm{Hg}$ in WWTP effluent depends on the treatment efficiencies, concentration of $\mathrm{Hg}$ in raw sewage, and by extension, sources of $\mathrm{Hg}$-containing waste to the plant. While loadings of $\mathrm{Hg}$ from WWTPs to surface waters are thought to be relatively small, most research reported in the peer-reviewed literature on $\mathrm{Hg}$ in WWTP effluent has not been comprehensive in its sampling design with regard to potential variability over hourly, weekly, and annual time scales (e.g.,Van Loon, 1974; Balogh and Liang, 1995; Gilmour and Bloom, 1995; Bodaly et al., 1998; Balcom et al., 2004; da Silva Oliveira et al., 2007; Gbondo-Tugbawa et al., 2010; Fricke et al., 2015). Routine systematic sampling is needed to understand temporal variation of $\mathrm{Hg}$ concentrations and loadings in WWTP effluent.

The primary goal of this study was to quantify temporal variation in the concentration of total Hg in effluent from two WWTPs throughout a 13-month period to better constrain uncertainty of $\mathrm{Hg}$ flux estimates. Additionally, I examined relationships 
between total $\mathrm{Hg}$, nitrate, $\mathrm{pH}$, carbonaceous biochemical oxygen demand (CBOD), and total suspended solids (TSS) in effluent. I also conducted multipoint sampling at critical components of the treatment process to identify $\mathrm{Hg}$ removal efficiencies.

\section{Research Hypotheses}

1) The two WWTPs in this study will remove $>90 \%$ of $\mathrm{Hg}$ from influent before it is discharged, which is consistent with observations at most other plants. This hypothesis was examined by paired comparison of $\mathrm{Hg}$ concentrations in influent and effluent.

2) Removal efficiency of $\mathrm{Hg}$ by the two WWTPs will be consistent throughout the year. This hypothesis was examined by paired comparison of $\mathrm{Hg}$ concentrations in influent and effluent at both WWTPs.

3) Concentrations of $\mathrm{Hg}$ in effluent will not vary substantially throughout a 24-h period. Wastewater flows through several treatment steps and at some points in the process, wastewater is returned to previous stages and mixed with process influent. Mixing of partially treated and untreated wastewater will lead to little variation of $\mathrm{Hg}$ concentrations in effluent throughout the day. This hypothesis was examined by hourly sampling of effluent at one of the WWTPs during a 24-h period.

4) The effluentô monthly averaged $\mathrm{Hg}$ concentrations and discharge fluxes will be consistent throughout the year. Monthly variability was tested by multiple comparisons of $\mathrm{Hg}$ concentrations and effluent fluxes calculated as the product of concentration and instantaneous discharge. 
5) Neither WWTP will be a major source of Hg to rivers into which they discharge their effluent, as observed for other WWTPs. This hypothesis was examined by comparison of the mean annual discharge flux and associated riverine $\mathrm{Hg}$ flux.

\section{METHODS}

\section{Wastewater Treatment Plants}

The current study examined variations in $\mathrm{Hg}$ concentration over hourly to annual time scales from two differently sized WWTPs in southwest Ohio. The Ford Road WWTP in Xenia, OH, (Xenia WWTP) has a peak flow of $45,000 \mathrm{~m}^{3} / \mathrm{d}$ of wastewater and treats, on average, $8,300 \mathrm{~m}^{3} / \mathrm{d}$ before discharging treated effluent into the Little Miami River. In contrast, the City of Dayton WWTP (Dayton WWTP), which discharges to the Great Miami River, has the capacity to treat $270,000 \mathrm{~m}^{3} / \mathrm{d}$ and processes, on average, about 170,000 $\mathrm{m}^{3}$ of wastewater daily (City of Dayton, 2010; Ohio EPA, 2012). Effluent from Dayton WWTP is discharged to the Lower Great Miami River and can account for as much as $40 і ̈ 50 \%$ of total river flow at the discharge point during low-flow conditions in late summer (City of Dayton, 2010). About 95\% of the wastewater input to the Xenia facility comes from residences and about $5 \%$ is from commercial sources. The Dayton WWTP receives about $6 \%$ of its wastewater input from permitted industries and the remainder flow is from commercial and residential sources and non-permitted industries. Permitted industries are those that are accounted for in the influent and are required to perform pre-treatment before discharging wastewater to the WWTPs. Non-permitted industries, however, do not have permits to discharge wastewater to the WWTPs, do not perform pre-treatment, and cannot be easily quantified. Neither WWTP treats surface 
runoff. Both plants treat wastewater by screening, raw pumping, grit removal, aeration, and clarifying before discharging (Figure 1). Both facilities use secondary disinfection from May 1 to October 31, when river recreation is most prevalent; the Xenia WWTP disinfects effluent with ultraviolet radiation and the Dayton WWTP chlorinates.

\section{Effluent Sampling to Examine Temporal Variability}

Grab samples of treated wastewater effluent were collected from the Xenia and Dayton WWTPs during a 13-month period, from April 1, 2015 to April 28, 2016. Samples were collected at hourly (for diurnal assessment) or weekly intervals (for monthly and yearly assessments). Effluent was sampled by WWTP staff, who were trained in the use of ultra-clean sampling techniques (Lamborg et al., 2012), into scrupulously cleaned glass bottles for low-level $\mathrm{Hg}$ analysis (Hammerschmidt et al., 2011). Ultra-clean sampling techniques are necessary to avoid contamination when analyzing $\mathrm{Hg}$ at low levels. One 500-mL bottle was filled during each sampling event, concurrent with the plantô routine sampling for other water quality parameters. The $\mathrm{Hg}$ samples were stored in double zip-type plastic bags until they were analyzed at Wright

State University. Additional water quality parameters, including nitrate, $\mathrm{pH}, \mathrm{CBOD}$, and TSS were determined by the WWTP laboratories. These analyses were performed on effluent samples collected at the same time as the $\mathrm{Hg}$ samples and used sample collection, preservation, and procedures according to standard methods (APHA et al., 1995).

Hourly variation of $\mathrm{Hg}$ concentrations and efflux from the Xenia plant was examined by sampling effluent hourly during a 24-h period, from 9:00 am on August 26 


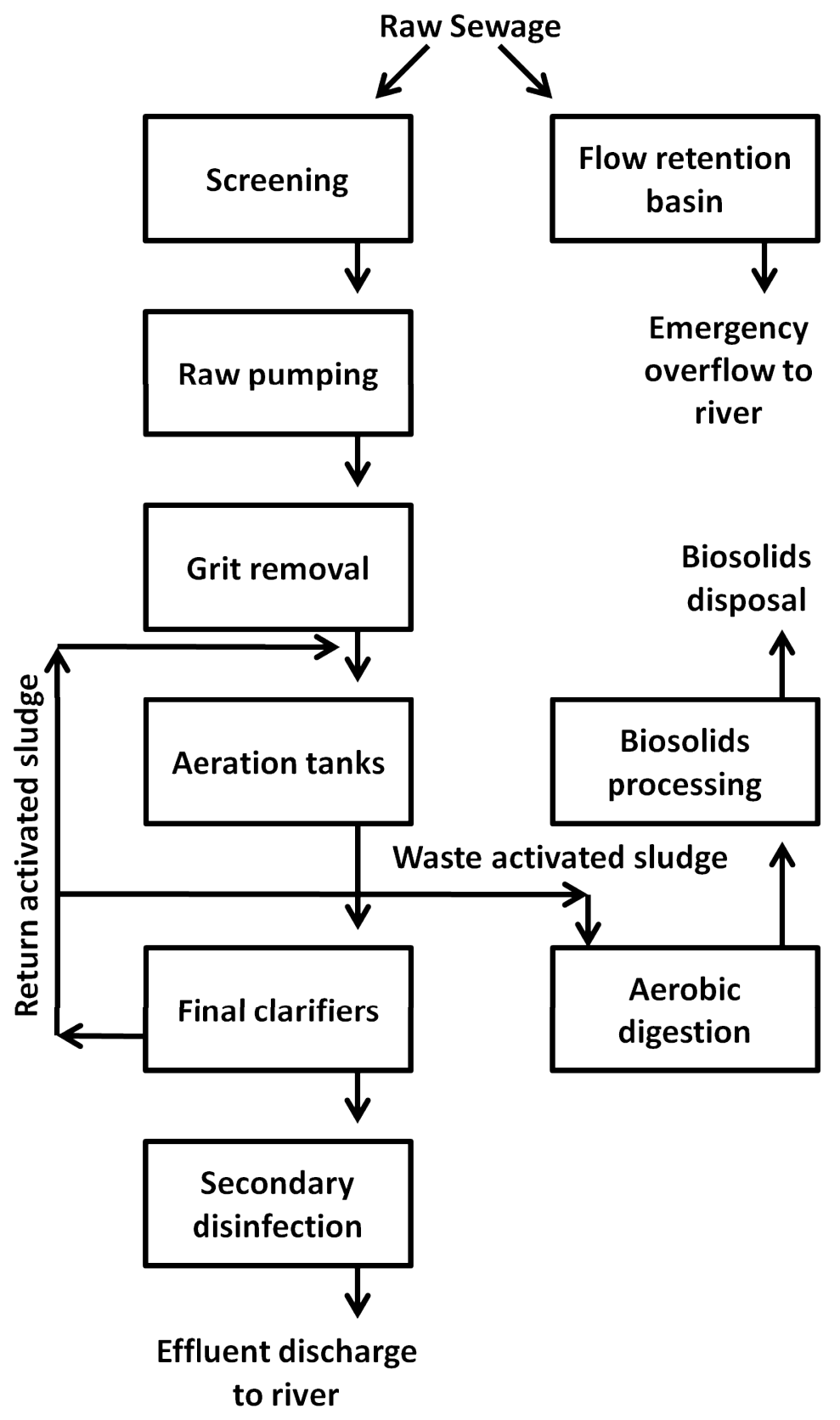

Figure 1. Generalization of the wastewater treatment process at the City of Dayton and the Ford Road (Xenia, Ohio) wastewater treatment plants. 
to 8:00 am on August 27, 2015. Additional water quality parameters and instantaneous discharge flow for each sampling time were provided by Xenia WWTP staff.

\section{Removal Efficiency}

The efficiency of $\mathrm{Hg}$ removal from wastewater was examined by paired sampling of raw wastewater (i.e., influent) and treated effluent at both the Xenia and Dayton WWTPs. Influent samples were collected once per month, during most months at Xenia and about half of the study months at Dayton, and associated effluent was sampled about 24 hours after influent sampling, consistent with the average residence time of wastewater in each plant. In addition, wastewater in the Xenia WWTP was sampled at multiple stages during the treatment process to identify important stages for $\mathrm{Hg}$ removal. Sampling points included raw or untreated wastewater influent, return activated sludge (RAS), raw sewage combined with RAS, waste activated sludge (WAS), and final process effluent (Figure 2). All samples were collected on the same day within one hour.

\section{River Water Sampling}

The contribution of $\mathrm{Hg}$ from the Xenia and Dayton WWTPs to the Little and Great Miami Rivers, respectively, was examined in context of the upstream riverine flux. The Great Miami River drains $9850 \mathrm{~km}^{2}$ of western Ohio. Land use in the Upper Great Miami River watershed, north of Dayton, is $79 \%$ agricultural, $9 \%$ developed land, and 9\% forest (Ohio EPA, 2013a). Great Miami River water was sampled monthly, upstream of the Dayton WWTP outfall, from shore directly into cleaned glass bottles. Great Miami River discharge, both annually and at the time of sampling, was obtained from the USGS 


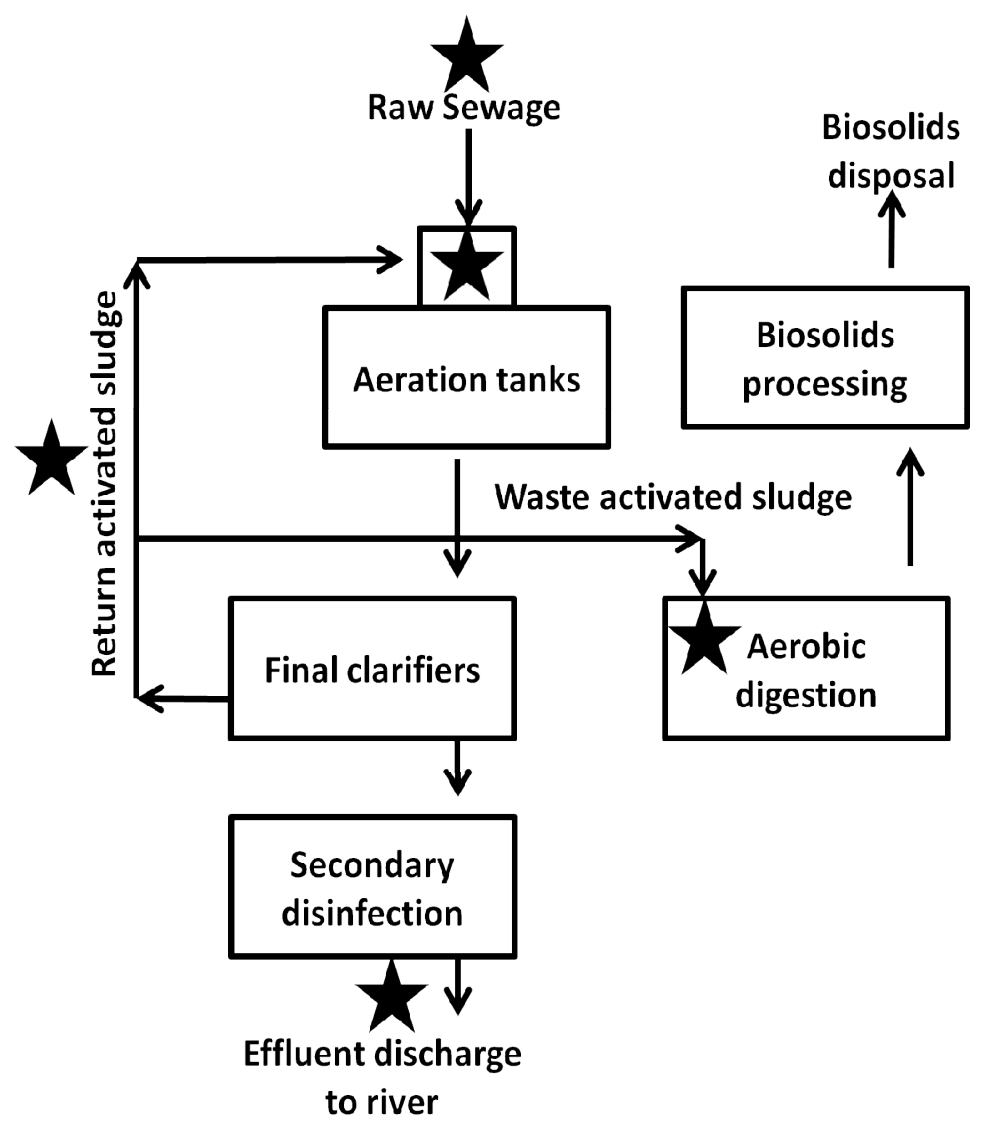

Figure 2. Sampling stages for multi-point study at Ford Road WWTP (Xenia, Ohio). 
gauge (03270500) located in Miamisburg, Ohio at river mile 63.4, upstream of the Dayton WWTP (USGS, 2016). The Little Miami River drains $4550 \mathrm{~km}^{2}$ of southwestern Ohio (Ohio EPA, 2013b). Upstream of Xenia, land use of the Little Miami River watershed is primarily agricultural with small residential areas (Sanders, 2002). Mercury concentrations in the Little Miami River have been determined previously (Naik and Hammerschmidt, 2011).

\section{Total Hg Analysis}

Total Hg in unfiltered wastewater and river water samples was quantified by dual$\mathrm{Au}$ amalgamation cold-vapor atomic fluorescence spectrometry (CVAFS). Unfiltered water samples were acidified to $0.1 \%$ with high-purity $\mathrm{HCl}$ (J.T. Baker Instra-Analyzed) and oxidized with $\mathrm{BrCl}$ (0.5\% final concentration; Bloom and Crecelius, 1983) for Ó12 h, pre-reduced with $\mathrm{NH}_{2} \mathrm{OH}$, and transferred to custom-made UConn Bubblers (Lamborg et al., 2012). Influent water was treated with a greater concentration of $\mathrm{BrCl}$ (up to $4.4 \%$ ) to fully oxidize the samples, indicated by a sustained yellow appearance. Mercury in water samples was reduced with $\mathrm{SnCl}_{2}$, purged from solution with $\mathrm{N}_{2}$, amalgamated onto Au and measured with cold-vapor atomic fluorescence spectrometry (Fitzgerald and Gill, 1979; Bloom and Fitzgerald, 1988). All analyses were calibrated with aqueous Hg standards traceable to the U.S. National Institute of Standards and Technology. Ten percent of the samples were measured in replicate. The mean $( \pm \mathrm{SD})$ relative percent difference between duplicate samples averaged $8.4 \pm 8.1 \%$ and ranged from 1.3 to $30.4 \%$ $(n=16$ pairs $)$. 


\section{Statistical Analysis}

Analysis of variance (ANOVA) and two-tailed studentôs $t$-tests were used to determine whether $\mathrm{Hg}$ concentrations and fluxes were significantly different among sampling periods. Least-squares linear regression and correlation analyses were used to identify significant correlations between variables. Differences and relationships were deemed significant when $p<0.05$. Microsoft Office Excel 2007 and SigmaPlot were used for statistical analyses.

\section{RESULTS AND DISCUSSION}

\section{Mercury in Influent}

Total $\mathrm{Hg}$ in influent did not differ significantly between Dayton and Xenia WWTPs ( $t$-test, $p=0.13$; Figure 3). During the 13-month period, total $\mathrm{Hg}$ in influent averaged $85 \pm 58 \mathrm{ng} / \mathrm{L}$ for the Dayton plant $(n=6)$ and $151 \pm 90 \mathrm{ng} / \mathrm{L}$ for Xenia $(n=11)$. These concentrations are within the range observed in previous studies (range $=2 i ̈ 860$ ng/L; Bodaly et al., 1998; Gbondo-Tugbawa et al., 2010). Unlike concentrations in effluent, there was no significant temporal trend of $\mathrm{Hg}$ in influent to the Xenia WWTP ( $p$ $=0.10$ ), and monthly averaged effluent and influent concentrations at Xenia were unrelated $(p=0.16, r=0.45)$. Likewise, no significant temporal trend was observed in influent to the Dayton WWTP $(p=0.17)$, and monthly averaged effluent and influent concentrations at Dayton were unrelated $(p=0.98, r=0.01)$. 


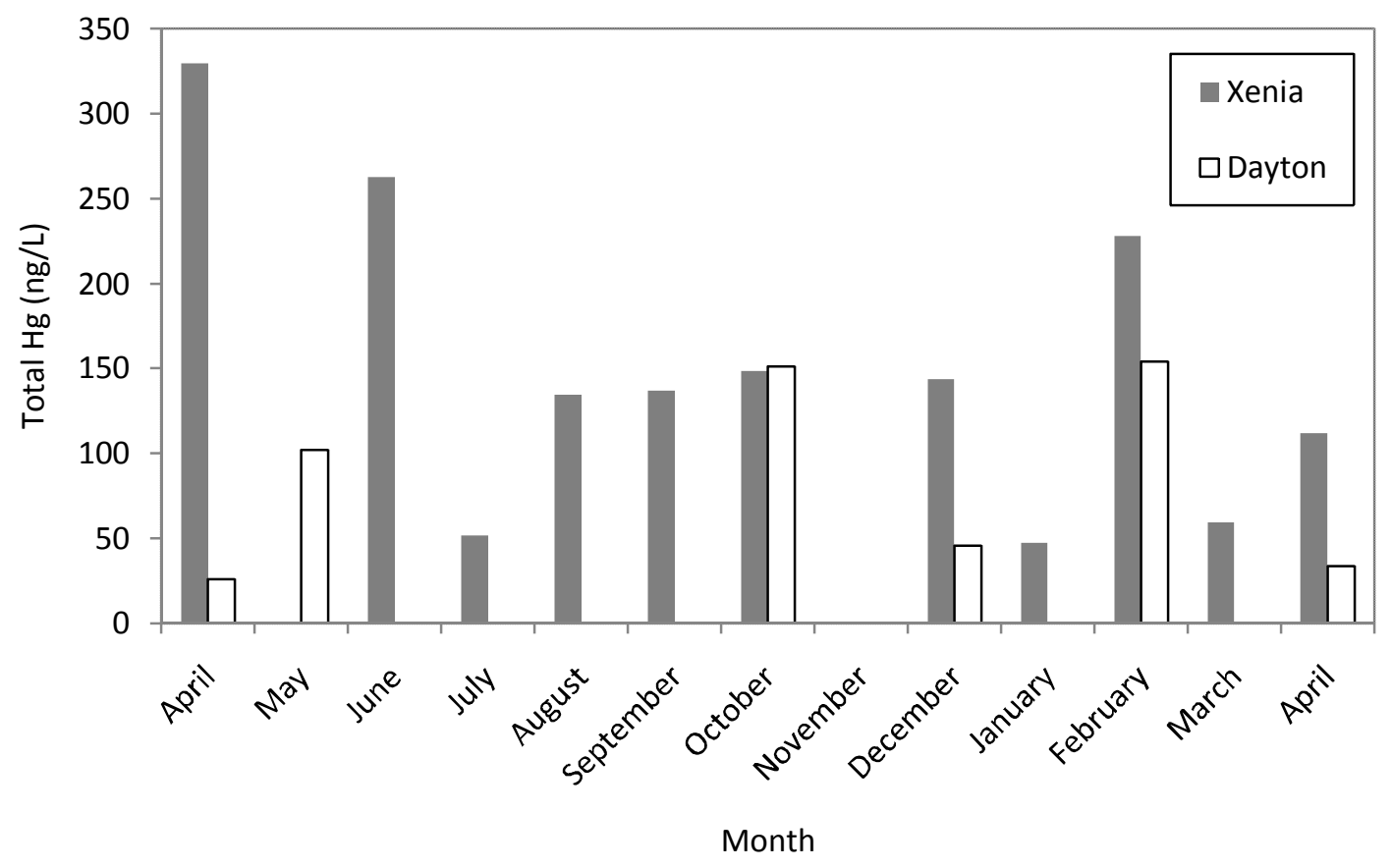

Figure 3. Concentrations of total mercury ( $\mathrm{Hg}$ ) in influent to the City of Dayton, Ohio, and Ford Road (Xenia, Ohio) WWTPs between April 2015 and April 2016. 


\section{Mercury in Effluent}

Effluent from both the Dayton and Xenia WWTPs contained relatively low concentrations of $\mathrm{Hg}$ (i.e., less than $6.3 \mathrm{ng} / \mathrm{L}$ ) throughout the 13-month sampling period. For the Dayton plant, the mean $( \pm \mathrm{SD})$ measured concentration of total $\mathrm{Hg}$ in effluent was $0.73 \pm 0.20 \mathrm{ng} / \mathrm{L}(n=50$; Figure 4). Monthly averaged Hg concentrations in Dayton effluent did not differ among months (ANOVA, $p>0.05$ ). At Xenia, total $\mathrm{Hg}$ in effluent averaged $4.18 \pm 1.45 \mathrm{ng} / \mathrm{L}(n=51)$ during the 13-month period. The mean $\mathrm{Hg}$ concentration was significantly greater for the Xenia WWTP than the Dayton WWTP $(t$ test, $p<0.001$; Figure 4). Both WWTPsômean annual Hg concentrations were within previously reported effluent ranges from other treatment facilities (range $=0.24 і ̈ 90$ ng/L; Bodaly et al., 1998; Balcom et al., 2004; Gbondo-Tugbawa et al., 2010; Fricke et al., 2015; Mao et al., 2016). Monthly averaged Hg concentrations were significantly greater in effluent from the Xenia plant compared to the Dayton plant during each month $(t$-test, $p<0.05)$ except for September and November, when concentrations were not significantly different between plants. Lower $\mathrm{Hg}$ concentrations in effluent from the Dayton WWTP compared to the Xenia facility may be attributed to either a greater volume of relatively low-Hg wastewater entering or more efficient $\mathrm{Hg}$ removal by the Dayton plant. In contrast to Dayton, $\mathrm{Hg}$ concentrations in effluent from the Xenia plant differed among months (ANOVA, $p<0.05$ ). Effluent from April 2016 had significantly less Hg than effluent from April, May, and June 2015 (Tukeyô post hoc, $t$-test, $p<0.04$ ).

Monthly differences of $\mathrm{Hg}$ concentrations in effluent at the Xenia WWTP were associated with a year-long trend of decreasing concentrations through time (monthly mean $\mathrm{Hg}$ concentration vs. study month number, $p<0.001, r=\bar{\imath} 0.81$ ), a pattern not 


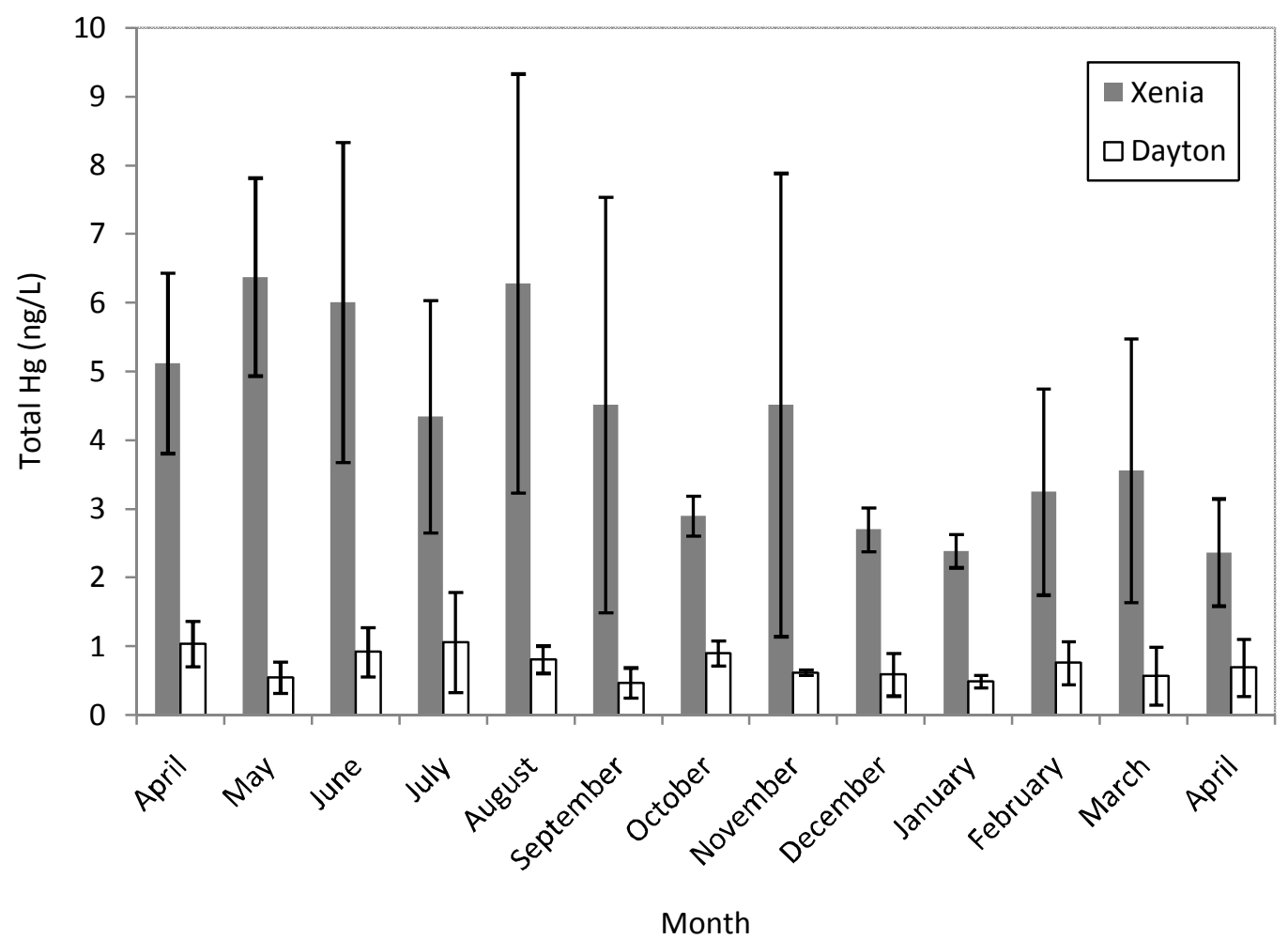

Figure 4. Mean $( \pm \mathrm{SD})$ total mercury $(\mathrm{Hg})$ concentrations in effluent from City of Dayton, Ohio and Ford Road (Xenia, Ohio) WWTPs from April 2015 to April 2016. 
observed in effluent from the Dayton WWTP $(p=0.1, r=0.49)$. The relatively long-term decrease of $\mathrm{Hg}$ concentrations in Xenia effluent, coupled with the significant difference between April 2015 and April 2016 at Xenia ( $t$-test, $p<0.01$ ), suggests either a temporal reduction of $\mathrm{Hg}$ inputs to the plant, an increasing efficacy of $\mathrm{Hg}$ removal over time, or possibly a longer-term cleansing of $\mathrm{Hg}$ from the plant.

Discharge fluxes were determined by taking the product of total $\mathrm{Hg}$ concentration in effluent and instantaneous discharge. The average discharge fluxes were $34.8 \pm 12.8$ and $10.7 \pm 4.7$ for the Dayton and Xenia WWTPs, respectively. As with total Hg concentrations in effluent, a year-long trend in decreasing discharge flux through time (monthly discharge flux vs. study month number, $p<0.001, r=\bar{\imath} 0.81$ ) was detected for the Xenia WWTP, but not the Dayton WWTP $(p=0.99, r=0.3)$.

Total Hg concentrations in Dayton WWTP effluent were unrelated to nitrate ( $p=$ $0.8)$, total phosphorus $(p=0.1), \mathrm{pH}(p=0.8)$, dissolved oxygen $(p=0.9)$, instantaneous discharge or flow $(p=0.7)$, TSS $(p=0.7)$, or CBOD $(p=0.98)$. Likewise, concentrations of total $\mathrm{Hg}$ were unrelated to nitrate $(p=0.07)$, total phosphorus $(p=0.7), \mathrm{pH}(p=0.8)$, dissolved oxygen $(p=0.5)$, instantaneous discharge $(p=0.5)$, or TSS $(p=0.1)$ in Xenia effluent. In contrast, total $\mathrm{Hg}$ was positively correlated with CBOD in Xenia effluent (correlation analysis, regression analysis, $p=0.03, r=0.6$; Figure 5). Carbonaceous biochemical oxygen demand is an operationally defined measurement of the concentration of oxygen used by microbes during the respiration of organic carbon in effluent. Decreasing concentrations of both total $\mathrm{Hg}$ and CBOD through the study period suggests that efficiencies of removal of both $\mathrm{Hg}$ and organic carbon by the treatment process may have been linked and improved over time. 


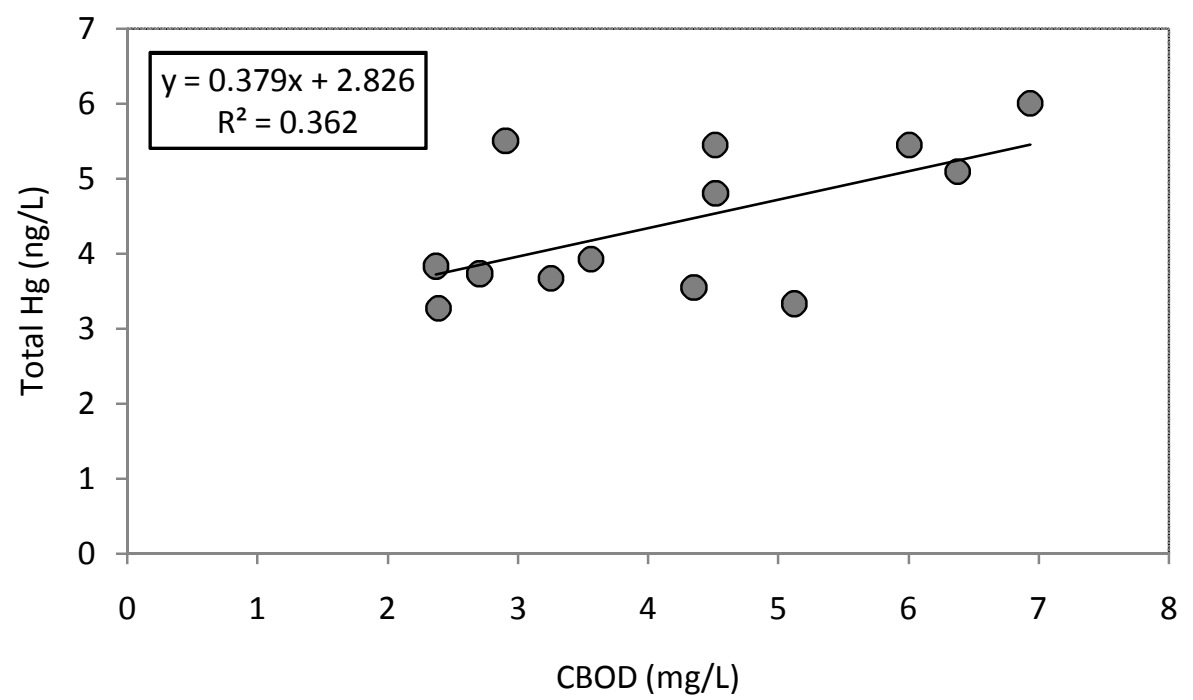

Figure 5. Correlation between total $\mathrm{Hg}$ concentration and carbonaceous biochemical oxygen demand (CBOD) in effluent from the Ford Road WWTP in Xenia, Ohio ( $p=$ $0.03)$. 


\section{Mercury Removal Efficiency}

Both WWTPs had a high efficiency of $\mathrm{Hg}$ removal from the waste stream. Efficiency of $\mathrm{Hg}$ removal was estimated for each month that paired influent and effluent samples were collected and calculated as the difference in $\mathrm{Hg}$ concentration divided by that in the influent. The $\mathrm{Hg}$ removal efficiency averaged $99 \pm 1 \%$ for Dayton and $97 \pm$ $2 \%$ for Xenia during the study period, both of which were within the range of estimates (88ї 99\%) for other North American and European WWTPs (Balogh and Liang, 1995; Gilmour and Bloom, 1995; Mugan, 1996; Bodaly et al., 1998; Gbondo-Tugbawa et al., 2010; Fricke et al., 2015). By this measure, Hg removal efficiencies did not change significantly through time for either the Dayton or Xenia WWTP (Figure 6; efficiency vs. study month number, $p$ Ó0.5), although this metric is inherently not as sensitive as comparison of $\mathrm{Hg}$ and CBOD concentrations in effluent (Figure 5).

The multi-point sampling study of wastewater at the Xenia WWTP included the following process locations: (1) raw or influent; (2) RAS; (3) raw combined with RAS (RAW+RAS stage); (4) WAS from the aerobic digestion tank (post treatment); and (5) effluent. It was revealed that total $\mathrm{Hg}$ concentrations varied dramatically among treatment steps, with an overall decrease from influent to effluent (Figure 7). Sludge contained the greatest concentration of $\mathrm{Hg}$. Mercury entering the aeration tank treatment system is removed from wastewater as it binds to the mixed liquor sludge. After the aeration tanks, the mixed liquor enters the final clarifier. During clarification, the settled solids are returned as RAS or removed as WAS to the aerobic digester. The clarifier effluent overflows weirs for disinfection and is then discharged as final effluent. During the clarification process, the wastewater continues to be treated and particulate matter is 


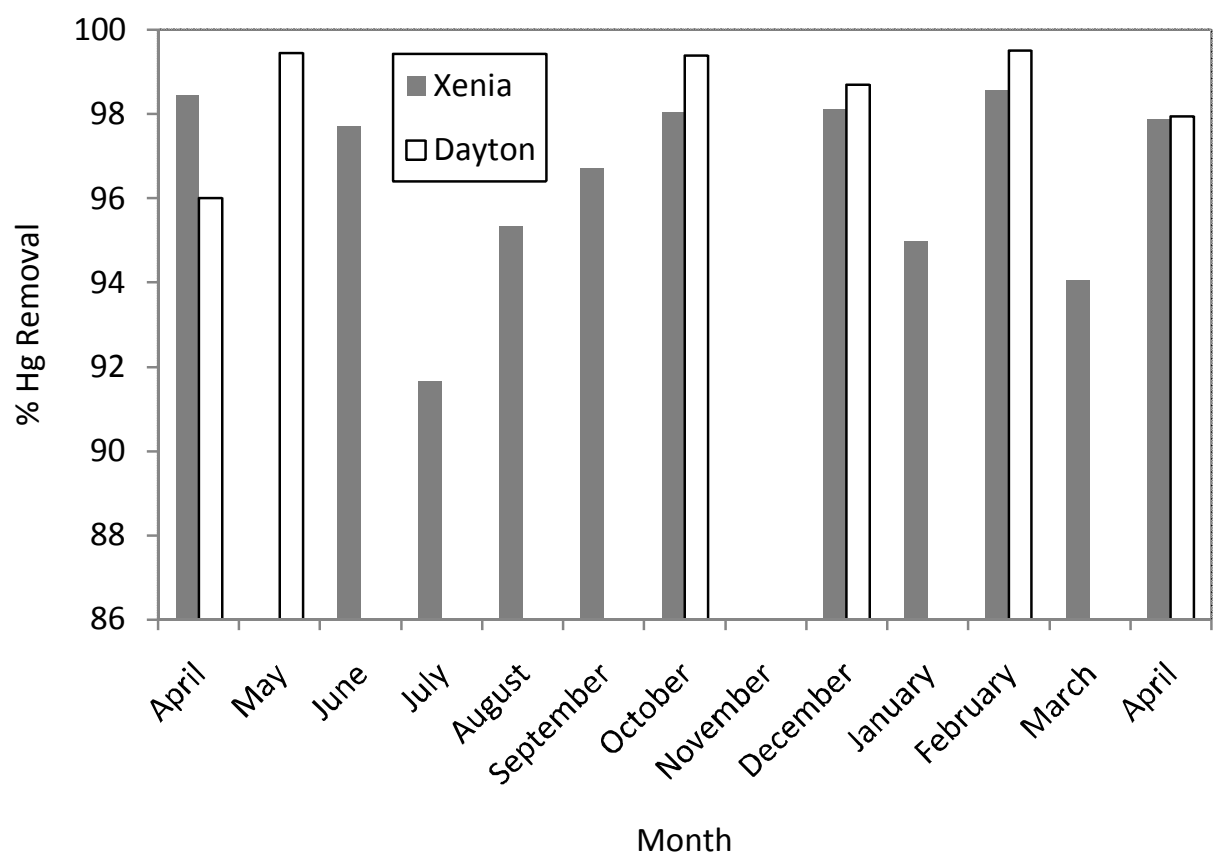

Figure 6. Efficiency of $\mathrm{Hg}$ removal from City of Dayton, Ohio and Ford Road (Xenia, Ohio) WWTPs from April 2015 to April 2016. 


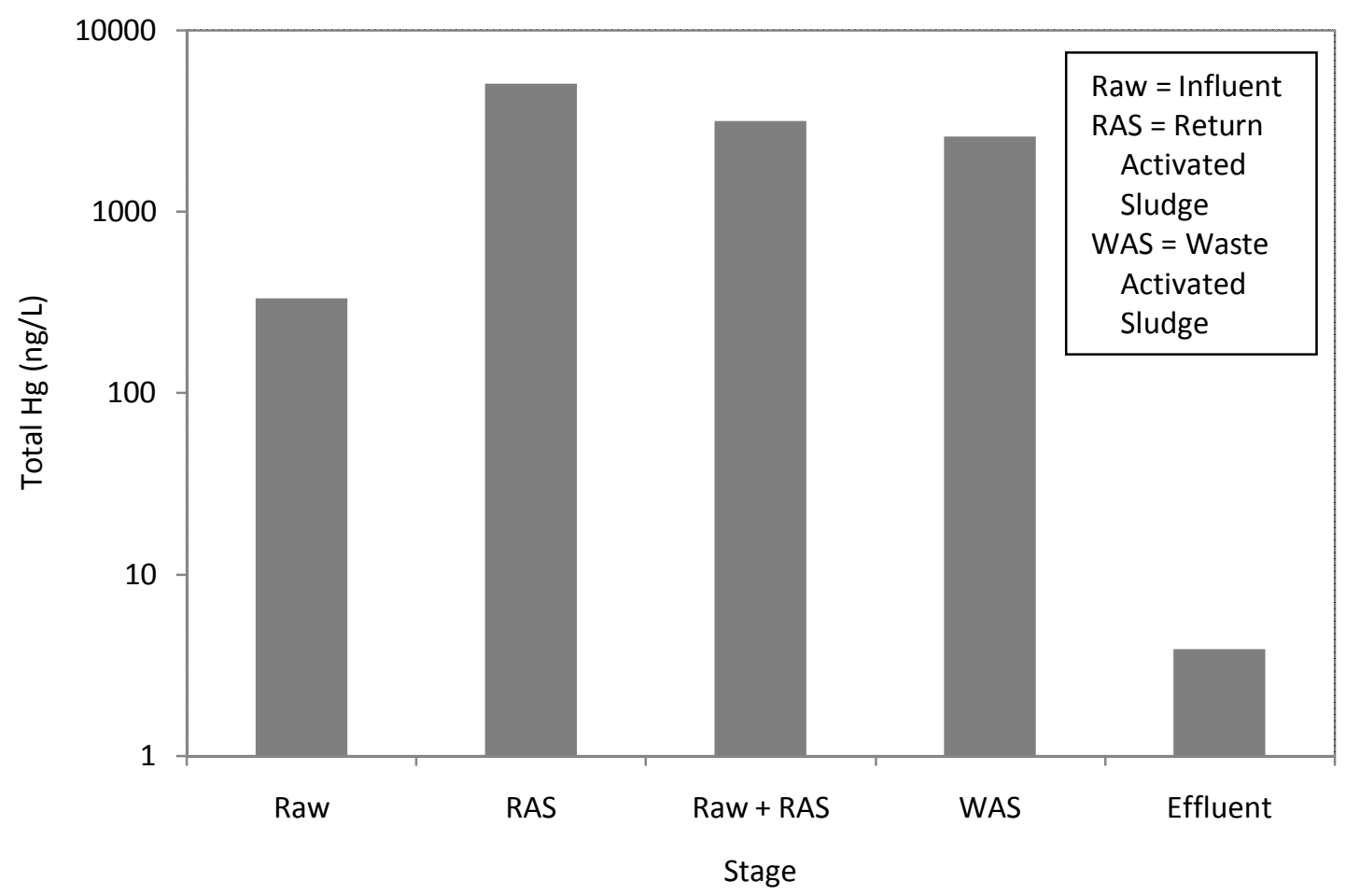

Figure 7. Total mercury $(\mathrm{Hg})$ concentrations in unfiltered wastewater at different points along the treatment process at the Ford Road Wastewater Treatment Plant in Xenia, Ohio. 
removed. This treatment and removal of particulate matter decreases the amount of mercury in the sewage before it is released as effluent. The sludge remains in the system, so sorbed $\mathrm{Hg}$ also is retained and concentrations increase over time as more $\mathrm{Hg}$ enters with raw influent even though sludge is removed as WAS. Previous studies also have observed concentration of Hg in sludge (Van Loon, 1974; Gilmour and Bloom, 1995; da Silva Oliveira et al., 2007; Gbondo-Tugbawa et al., 2010; Fricke et al., 2015; Mao et al., 2016).

Although most $\mathrm{Hg}$ is removed from wastewater before it is discharged to receiving waters, stabilized sludge from the aerobic digester is often used to amend soil for crop growth. Because sludge can contain elevated concentrations of $\mathrm{Hg}$, as well as other contaminants, concentrations of $\mathrm{Hg}$ in soil amended significantly (Granato et al., 1995). Sludge is not used to amend soils in which crops for human consumption are grown; however, the increase of $\mathrm{Hg}$ in the soil can lead to greater concentrations in runoff (Sloan et al., 2001) that may contribute to Hg loadings in waterways and contamination of aquatic environments (Van Loon, 1974).

\section{Diurnal Variation of Mercury in Effluent}

A 23-time point diurnal investigation to measure total $\mathrm{Hg}$ concentration in plant effluent took place in late August 2015 at the Xenia plant. Mercury concentrations in effluent ranged from 2.78 to $7.62 \mathrm{ng} / \mathrm{L}$, averaged $4.30 \pm 1.35 \mathrm{ng} / \mathrm{L}$, and varied by a factor of two (Figure 8). The mean $\mathrm{Hg}$ concentration during the diurnal study was consistent with and not significantly different from the average concentration of total $\mathrm{Hg}$ in Xenia effluent for the months of August and September $2015(5.30 \pm 2.99 \mathrm{ng} / \mathrm{L} ; t$-test, $p=0.4)$. 


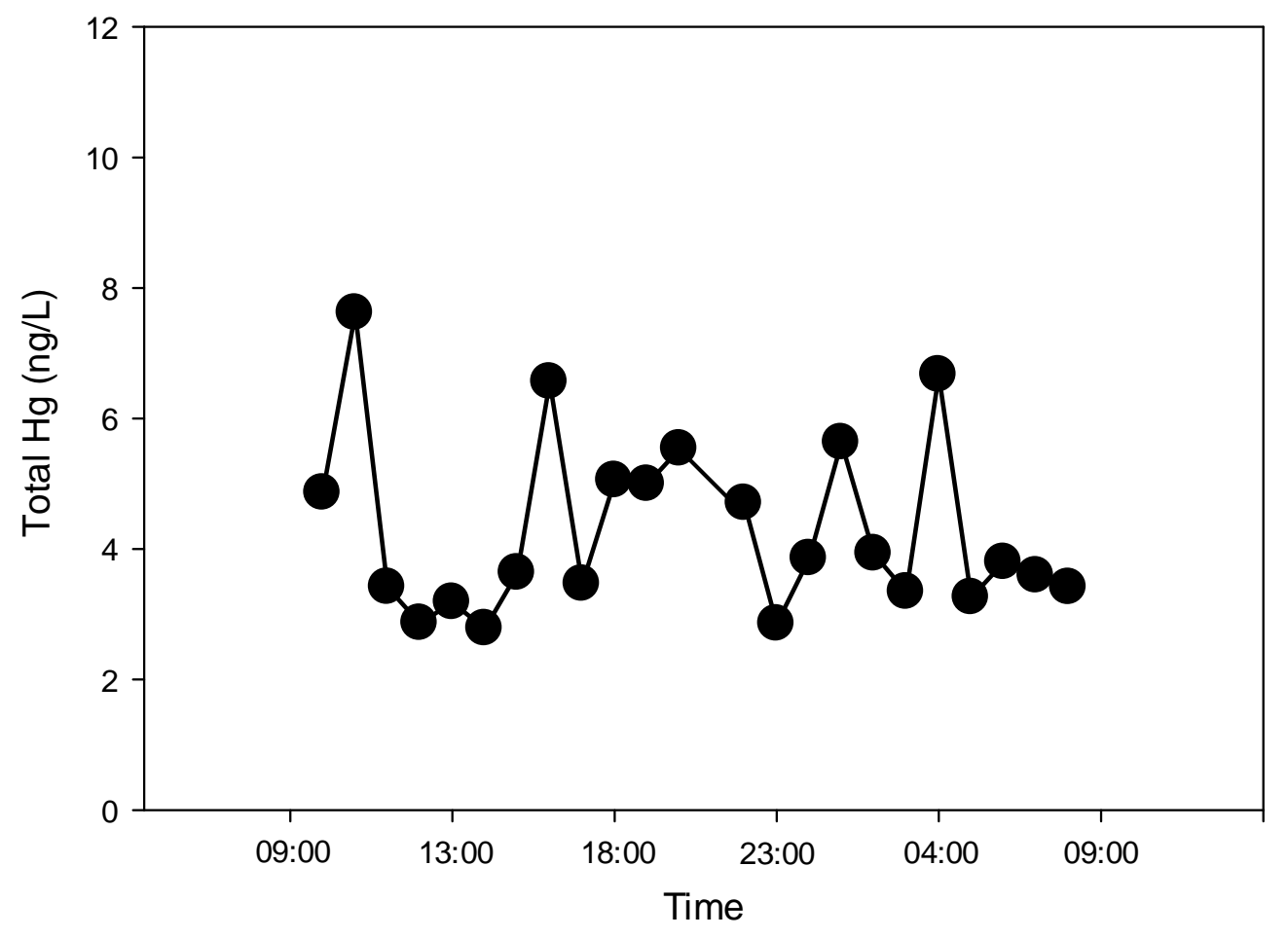

Figure 8. Total mercury $(\mathrm{Hg})$ concentrations in effluent sampled hourly from the Ford Road WWTP in Xenia, Ohio. 
The diurnal variation of $\mathrm{Hg}$ in effluent from the Xenia plant is comparable to the degree of variation among months for both the Dayton (range $=0.47$ ï $1.06 \mathrm{ng} / \mathrm{L}$ ) and Xenia plants (range $=2.37 \mathrm{ï} 6.38 \mathrm{ng} / \mathrm{L}$ ). Diurnal variability was unrelated to changes in instantaneous discharge (regression analysis, $p=0.8, r=0.05$ ). Little diurnal variation of $\mathrm{Hg}$ concentrations in effluent was expected because wastewater is well mixed throughout the treatment process when the process is controlled and has not experiences any issues.

\section{Significance to Receiving Waters}

Total $\mathrm{Hg}$ concentrations in unfiltered Great Miami River water upstream of the outflow from the Dayton WWTP were significantly greater than those in Dayton WWTP effluent ( $t$-test, $p<0.001$; Figure 9). Mercury concentrations in unfiltered Great Miami River water averaged $3.14 \pm 1.71 \mathrm{ng} / \mathrm{L}(n=12)$ during the study period and were within the range of concentrations measured in other southwest Ohio streams $(2.3 \ddot{i} 4.9 \mathrm{ng} / \mathrm{L}$; Naik and Hammerschmidt, 2011). As observed in other Dayton-area streams (Naik and Hammerschmidt, 2011), concentrations of $\mathrm{Hg}$ in the Great Miami River were positively correlated with instantaneous discharge measured upstream of the Dayton WWTP outflow $(\mathrm{p}=0.003, r=0.77$; Figure 10$)$.

To estimate the contribution of the Dayton and Xenia WWTPs to Hg loadings in receiving waters, an average flux of $\mathrm{Hg}$ in the river water flowing past the WWTP outflow was estimated and compared to effluent $\mathrm{Hg}$ fluxes from WWTPs. The fluvial $\mathrm{Hg}$ flux was estimated as the product of the mean daily river discharge and average concentration of $\mathrm{Hg}$ in river water. Similarly, the flux of $\mathrm{Hg}$ in effluent was estimated as the product of the mean daily discharge from the WWTP and average concentration of 


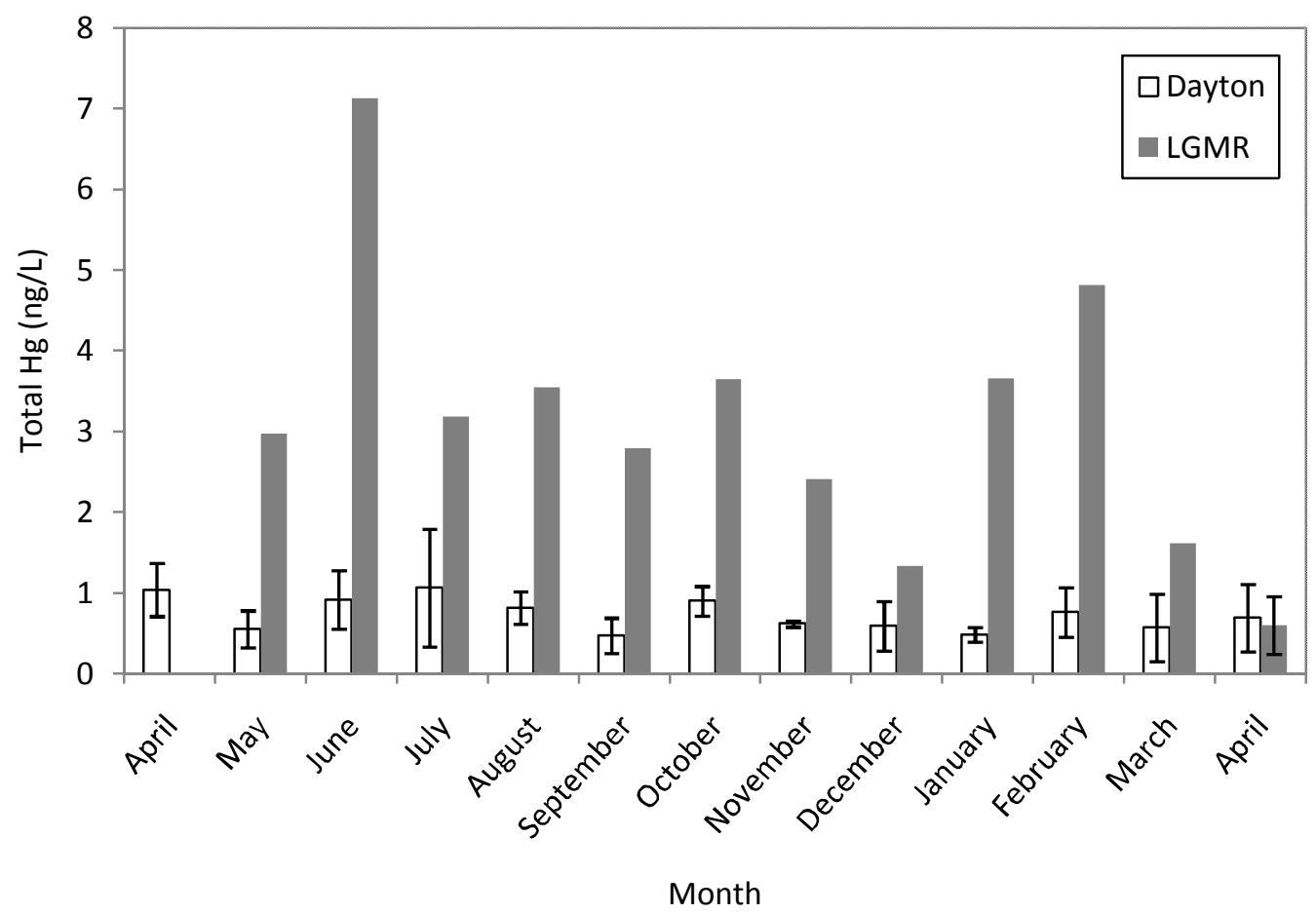

Figure 9. Monthly total mercury $(\mathrm{Hg})$ concentrations in effluent from the City of Dayton Wastewater Treatment Plant (mean \pm S.D.) and in the Lower Great Miami River (LGMR) upstream of the outflow pipe. 


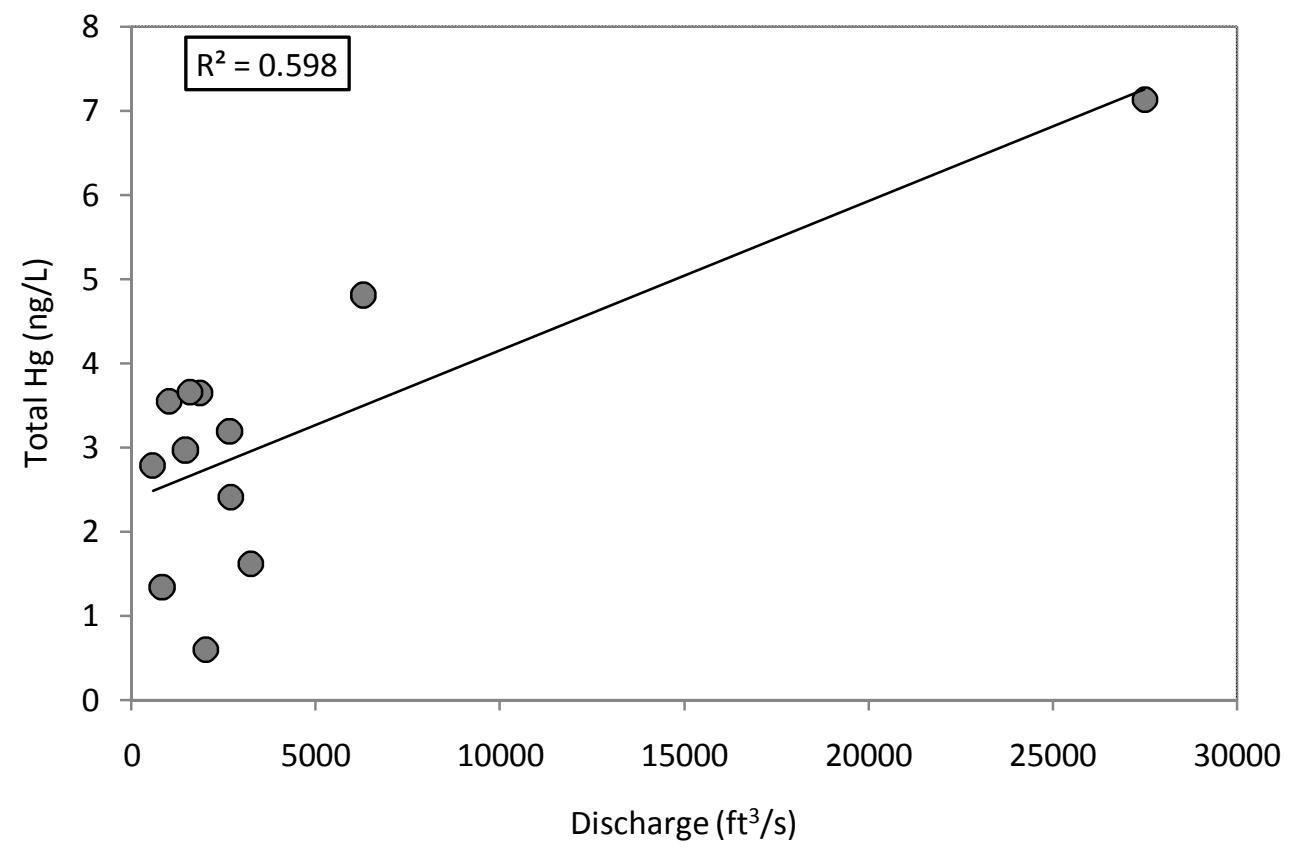

Figure 10. Correlation between total Hg in the Great Miami River and instantaneous discharge upstream of the City of Dayton Wastewater Treatment Plant outflow ( $p=$ $0.003)$. 
$\mathrm{Hg}$ in effluent. Mean flux of $\mathrm{Hg}$ in effluent was divided by the flux of $\mathrm{Hg}$ in the river to calculate the percent contribution of the WWTP to Hg loadings in the river. The average discharge of the Great Miami River during the study period was $1.1 \times 10^{7} \mathrm{~m}^{3} /$ day (river $\mathrm{Hg}$ flux $=35 \pm 18 \mathrm{~g} /$ day). Accordingly, and with a mean daily discharge of 170,000 $\mathrm{m}^{3} /$ day and $\mathrm{Hg}$ concentration of $0.73 \pm 0.20 \mathrm{ng} / \mathrm{L}$, effluent from the Dayton WWTP contributes $0.12 \pm 0.03 \mathrm{~g} / \mathrm{day}$ of $\mathrm{Hg}$, or about $0.2 \mathrm{i} 0.9 \%$ of the total $\mathrm{Hg}$ load in the Great Miami River in Dayton. In comparison, mean discharge of the Little Miami River was about $1 \times 10^{6} \mathrm{~m}^{3} /$ day and $\mathrm{Hg}$ concentrations in the Little Miami River averaged $2.8 \pm 1.7$ ng/L (Naik and Hammerschmidt, 2011), resulting in a riverine $\mathrm{Hg}$ flux of $2.8 \pm 1.7 \mathrm{~g} / \mathrm{day}$ past the Xenia plant. Effluent from the Xenia plant $\left(8300 \mathrm{~m}^{3} / \mathrm{day}, 4.18 \pm 1.45 \mathrm{ng} \mathrm{Hg} / \mathrm{L}\right)$ is estimated to contribute $0.035 \pm 0.012 \mathrm{~g} \mathrm{Hg} /$ day to the Little Miami River, or $0.5 \mathrm{i} 4 \%$ of the total $\mathrm{Hg}$ loading in the river. The uncertainty in the percent contribution of the Xenia effluent to the Little Miami River is due mostly to variability in river $\mathrm{Hg}$ concentrations. Estimates of relative contributions of Hg from Dayton and Xenia WWTPs are similar to range, typically $<2 \%$ observed in most other studies (Bodaly et al., 1998; Balcom et al., 2004).

\section{CONCLUSION}

Over the 13-month study period, the two WWTPs effectively removed almost all of the $\mathrm{Hg}$ from influent before discharging treated water to rivers. As hypothesized, both the Dayton and Xenia WWTP remove over 90\% of $\mathrm{Hg}$ from wastewater. I hypothesized that removal efficiency of $\mathrm{Hg}$ would be consistent throughout the year. As expected, there was no significant variation in $\mathrm{Hg}$ concentrations in effluent from the Dayton 
facility among months. However, the Xenia WWTP experienced a significant decrease of $\mathrm{Hg}$ concentrations in effluent over the study period. Likewise, the discharge flux was consistent for the Dayton WWTP, as hypothesized. However, a decrease in discharge flux over the study period was observed for the Xenia facility.

As expected, Hg concentrations in effluent did not vary substantially throughout a 24-h period at the Xenia WWTP. Although there was variation in Hg concentrations, this variation was comparable to that observed between weeks in August and September bracketing the 24-h testing period. Wastewater is well mixed because it returns to previous stages after several steps of the treatment process. This mixing occurs only when the treatment process is controlled and has not experienced any issues. Also, the multi-point study revealed that the highest concentration of $\mathrm{Hg}$ is found in the RAS stage of the treatment process. The Hg binds to solids in the activated sludge and remains in the system until sludge is removed by workers at the facility.

The Great and Little Miami Rivers are important sites of recreation for their surrounding communities. The Dayton WWTP removed 99\% of Hg from wastewater and contributed only $0.210 .9 \%$ to Hg loadings in the Great Miami River. Likewise, the Xenia facility eliminated $97 \%$ of $\mathrm{Hg}$ in wastewater and contributed $0.5 \mathrm{i} 4 \%$ to $\mathrm{Hg}$ loadings in the Little Miami River during the study period. As a result of the observed removal efficacy at these two WWTP, these facilities are not significant sources of $\mathrm{Hg}$ to the Great and Little Miami Rivers into which they discharge effluent.

Similar studies should be completed in other areas of the United States to learn whether other facilities are effectively removing $\mathrm{Hg}$ from wastewater. Facilities that utilize different treatment methods, including those that treat combined sewage, should 
be examined. Future research should also focus on non-point sources, such as agricultural land, and their contribution to $\mathrm{Hg}$ loadings in rivers and other receiving waters. The fate and impact of Hg in sludge from WWTPs should also be a focus of future research.

Although there was little temporal variation in $\mathrm{Hg}$ concentrations at the Dayton WWTP, concentrations in effluent from the Xenia facility did vary during the study period. This highlights the importance of systematic sampling and taking care not to generalize from only a few samples taken during a brief period of time, as well as from one sample site to another. 


\section{REFERENCES}

APHA, American Water Works Association, and Water Environment Federation. (1995). Standard methods for the examination of water and wastewater. American Public Health Association, American Water Works Association, and Water Pollution Control Federation. 19th edition, Washington, D.C.

Balcom, P. H., Fitzgerald, W. F., Vandal, G. M., Lamborg, C. H., Rolfhus, K. R., Langer, C. S., and Hammerschmidt, C. R. (2004). Mercury sources and cycling in the Connecticut River and Long Island Sound. Marine Chemistry, 90(1-4), 53 ï 74.

Balcom, P. H., Hammerschmidt, C. R., Fitzgerald, W. F., Lamborg, C. H., and OâConnor, J. S. (2008). Seasonal distributions and cycling of mercury and methylmercury in the waters of New York/New Jersey Harbor Estuary. Marine Chemistry, 109(12), 1 ï 17 .

Balogh, S. and Liang, L. (1995). Mercury pathways in municipal wastewater treatment plants. Water, Air, and Soil Pollution, 80(1), 118111190.

Benoit, J. M., Gilmour, C. C., Heyes, A., Mason, R. P., and Miller, C. L. (2003). Geochemical and biological controls over methylmercury production and degradation in aquatic ecosystems. In ACS Symposium Series, 835, $262 i ̈ 297$. American Chemical Society. Washington, D.C.

Bloom, N. S. and Crecelius, E. A. (1983). Determination of mercury in seawater at subnanogram per liter levels. Marine Chemistry, 14(1), $490 ̈ 59$. 
Bloom, N. S. and Fitzgerald, W. F. (1988). Determination of volatile mercury species at the picogram level by low-temperature gas chromatography with cold-vapour atomic fluorescence detection. Analytica Chimica Acta, 208, 151 ï 161.

Bodaly, R. D., Rudd, W. M., and Flett, R. J. (1998). Effect of urban sewage treatment on total and methyl mercury concentration in effluents. Biogeochemistry, 40(2-3), $279 \ddot{1} 291$.

City of Dayton. (2010). Facts about the wastewater treatment plant. Retrieved June 10, 2016 from http://water.cityofdayton.org/water/wwabout.asp.

Covelli, S., Faganeli, J., Horvat, M., and Brambati, A. (2001). Mercury contamination of coastal sediments as the result of long-term cinnabar mining activity (Gulf of Trieste, northern Adriatic Sea). Applied Geochemistry, 16(5), 541 ï 558.

da Silva Oliveira, A., Bocio, A., Beltramini Trevilato, T. M., Magosso Takayanagui, A. M., Domingo, J. L., and Segura-Muñoz, S. I. (2007). Heavy metals in untreated/treated urban effluent and sludge from a biological wastewater treatment plant. Environmental Science and Pollution Research, 14(7), 483 ï 489.

Depew, D. C., Basu, N., Burgess, N. M., Campbell, L. M., Devlin, E. W., Drevnick, P. E., Hammerschmidt, C. R., Murphy, C. A., Sandheinrich, M. B., and Wiener, J. G. (2012). Toxicity of dietary methylmercury to fish: derivation of ecologically meaningful threshold concentrations. Environmental Toxicology and Chemistry, 31(7), $1536 і ̈ 1547$.

Fitzgerald, W. F., Engstrom, D. R., Lamborg, C. H., Tseng, C.-M., Balcom, P. H., and Hammerschmidt, C. R. (2005). Modern and historic atmospheric mercury fluxes 
in northern Alaska: global sources and arctic depletion. Environmental Science and Technology, 39(2), 557ї 568.

Fitzgerald, W. F. and Gill, G. A. (1979). Subnanogram determination of mercury by twostage gold amalgamation and gas phase detection applied to atmospheric analysis. Analytical Chemistry, 51(11), 1714ї 1720.

Fricke, I., Götz, R., Schleyer, R., and Pütmann, W. (2015). Analysis of sources and sinks of mercury in the urban water cycle of Frankfurt am Main, Germany. Water, 7 , $6097 і ̈ 6116$.

Gbondo-Tugbawa, S. S., McAlear, J. A., Driscoll, C. T., and Sharpe, C. W. (2010). Total and methyl mercury transformations and mass loadings within a wastewater treatment plant and the impact of the effluent discharge to an alkaline hypereutrophic lake. Water Research, 44(9), $2863 і ̈ 2875$.

Gehrke, G. E., Blum, J. D., and Marvin-DiPasquale, M. (2011). Sources of mercury to San Francisco Bay surface sediment as revealed by mercury stable isotopes. Geochimica et Cosmochimica Acta, 75(3), 691 ï 705.

Ghosh, S., Sadhukhan, P. C., Ghosh, D. K., Chaudhuri, J., and Mandal, A. (1996). Volatilization of mercury by resting mercury-resistant bacterial cells. Bulletin of Environmental Contamination and Toxicology, 56(2), 25910264.

Gilmour, C. C. and Bloom, N. S. (1995). A case study of mercury and methylmercury dynamics in a Hg-contaminated municipal wastewater treatment plant. Water, Air, and Soil Pollution, 80(1), 799 ï 803.

Granato, T. C., Pietz, R. I., Gschwind, J., and Lue-Hing, C. (1995). Mercury in soils and crops from fields receiving high cumulative sewage sludge applications: 
validation of U. S. EPAQ̂s risk assessment for human ingestion. Water, Air, and Soil Pollution, 80(1), $1119 і 11127$.

Hammerschmidt, C. R., Bowman, K. L., Tabatchnick, M. D., and Lamborg, C. H. (2011). Storage bottle material and cleaning for determination of total mercury in seawater. Limnology and Oceanography: Methods, 9(10), $426 i ̈ 431$.

Lamborg, C. H., Hammerschmidt, C. R., Gill, G. A., Mason, R. P, and Gichuki, S. (2012). An intercomparison of procedures for the determination of total mercury in seawater and recommendations regarding mercury speciation during GEOTRACES cruises. Limnology and Oceanography: Methods, 10(2), 90ї 100.

Mahaffey, K. R., Clickner, R. P., and Jeffries, R. A. (2009). Adult womenô blood mercury concentrations vary regionally in the United States: association with patterns of fish consumption (NHANES 1999ï 2004). Environmental Health Perspectives, 117(1), $47 і ̈ 53$.

Mao, Y., Cheng, L., Ma, B., and Cai, Y. (2016). The fate of mercury in municipal wastewater treatment plants in China: significance and implications for environmental cycling. Journal of Hazardous Materials, 306, 1 ï 7.

Missouri Department of Natural Resources. (2016). Water Quality Parameters. Retrieved August 10, 2016 from http://dnr.mo.gov/env/esp/waterquality-parameters.htm.

Mugan, T. J. (1996). Quantification of total mercury discharges from publicly owned treatment works to Wisconsin surface waters. Water Environment Research, 6(2), $229 і ̈ 234$. 
Naik, A. P. and Hammerschmidt, C. R. (2011). Mercury and trace metal partitioning and fluxes in suburban Southwest Ohio watersheds. Water Research, 45(16), $5151 \ddot{i}$ 5160.

Ohio EPA. (2013a). Great Miami River watershed. Retrieved June 10, 2016 from http://www.epa.state.oh.us/dsw/tmdl/GreatMiamiRiver.aspx.

Ohio EPA. (2013b). Little Miami River watershed. Retrieved June 10, 2016 from http://epa.ohio.gov/dsw/tmdl/LittleMiamiRiver.aspx.

Pirrone, N., Cinnirella, S., Feng, X., Finkelman, R. B., Friedli, H. R., Leaner, J., Mason, R., Mukherjee, A. B., Stracher, G. B., Streets, D. G., and Telmer, K. (2010). Global mercury emissions to the atmosphere from anthropogenic and natural sources. Atmospheric Chemistry and Physics, 10, 5951 ï 5964.

Saha, D. K., Ghosh, S., Chaudhuri, J., and Mandal, A. (2006). Mercury resistance in bacterial strains isolated from hospitals and clinics. Bulletin of Environmental Contamination and Toxicology, 77(1), $88 і ̈ 95$.

Sanders, R. E. (2002). A Guide to Ohio Streams. Ohio Chapter of the American Fisheries Society, Columbus, $\mathrm{OH}$.

Sloan, J. J., Dowdy, R. H., Balogh, S. J., and Nater, E. (2001). Distribution of mercury in soil and its concentration in runoff from a biosolids-amended agricultural watershed. Journal of Environmental Quality, 30(6), $2173 \mathrm{ï} 2179$.

State of Ohio Environmental Protection Agency. (2012). Biological and water quality study of the Lower Great Miami River watershed Butler, Hamilton, Montgomery, Preble, and Warren Counties. Ohio EPA Technical Report EAS/2012-5-7. 
Swain, E. B., Engstrom, D. R., Brigham, M. E., Henning, T. A., and Brezonik, P. L. (1992). Increasing rates of atmospheric mercury deposition in midcontinental North America. Science, 257(5071), $784 і ̈ 787$.

Thomas, M. A., Conaway, C. H., Steding, D. J., Marvin-DiPasquale, M., Abu-Saba, K. E., and Flegal, A. R. (2002). Mercury contamination from historic mining in water and sediment, Guadalupe River and San Francisco Bay, California. Geochemistry: Exploration, Environment, Analysis, 2, $211 \mathrm{ï} 217$.

U.S. EPA. (2004). Local Limits Development Guidance. Report EPA 833-R-04-002A, Washington, D.C.

USGS. USGS 03271601 Great Miami River below Miamisburg OH. (2016). Retrieved June 10, 2016 from http://nwis.waterdata.usgs.gov/usa/nwis/uv/?site_no=03270500.

Van Loon, J. C. (1974). Mercury input to the environment resulting from products and effluents from municipal sewage treatment plants. Environmental Pollution, 7(2), $141 \mathrm{ï} 147$.

Zahir, F., Rizwi, S. J., Haq, S. K., and Khan, R. H. (2005). Low dose mercury toxicity and human health. Environmental Toxicology and Pharmacology, 20(2), 351ї 360. 